\title{
HEPATITIS C;
}

THE INCIDENCE OF RELAPSE AMONG PATIENTS TAKING INTERFERON THERAPY

1. M.B.B.S, M.D (USA),

FCPS-II Trainee Internal Medicine,

Department of Medicine

DHQ Teaching Hospital, Sargodha.

2. MBBS, PGY 1/

Department of Medicine

Bronx Lebanon Hospital, Center NY, USA.

3. $M D$,

House Physician,

DHQ Teaching Hospital, Sargodha

4. MBBS

Woman Medical Officer,

DHQ Teaching Hospital, Sargodha.

5. MBBS, FCPS,

Supervisor CPSP

District Physician

DHQ Teaching Hospital, Sargodha

Correspondence Address:

Dr. Muhammad Khuram Nouman Department of Medicine

DHQ Teaching Hospital, Sargodha

doctorkhurrum@hotmail.com

Article received on:

22/05/2017

Accepted for publication:

$15 / 11 / 2017$

Received after proof reading:

28/02/2018

\section{INTRODUCTION}

It is estimated approximately $3 \%$ of the world population is infected with Hepatitis C, which is 170 million worldwide. ${ }^{1}$ It is reported that 2.7 million chronically infected persons in the United States only. ${ }^{1}$ Hepatitis $C$ virus $(\mathrm{HCV})$ is the most communal source of non-A, non-B viral hepatitis in the world. ${ }^{2,3}$ The disease is illusory, and the majority of patients do not acquire jaundice at its onset. ${ }^{4,5}$ Treatment of hepatitis $\mathrm{C}$ with interferon attained a sustained virological response (SVR) in almost $50 \%$ of the patients with HCV infection. Viral genotype is important to determine the response. ${ }^{6-10}$ At the end of treatment (EOT) it is presumed HCV eradication in most of the patients accomplishing unnoticeable serum HCV RNA. This remains negative unless 24 weeks reached. ${ }^{11}$ The odds of HCV appearance are low; once a justifiable virological response has been accomplished. ${ }^{12,13}$

Relapses usually occur in HCV patients after the successful EOT within the first 12 weeks in almost all cases with interferon therapy. ${ }^{14}$ The present study aims to provide the incidence of relapse of $\mathrm{HCV}$ in patients taking interferon therapy and also to identify the predictors for relapse.

\section{MATERIAL AND METHODS}

It was a retrospective observational study, conducted at Department of Medicine, DHQ Teaching Hospital, Sargodha. The study period was of two years. A total of 60 patients were retrieved from hospital records for this study. The exclusion criteria include the patients co- infected with hepatitis B virus or HIV, whereas patients of either sex, chronic hepatitis $\mathrm{C}$ who were interferon naive and who initiated treatment with interferon at the hospital in Sargodha. Patient's detailed medical history, physical examination and demographics were collected, moreover the viral load, genotypes, doses of treatment, and administration time etc was noted as well. Later Only patients who attained a serum HCV RNA 
level $10 \mathrm{IU} / \mathrm{mL}$ at the planned EOT were analyzed. All the required parameter readings were noted through standard procedures.

\section{Statistical analysis}

All the collected data was stored electronically \& analyzed later by using SPSS version 20 . Descriptive statistics were applied to calculate mean and standard deviation. Frequency distribution and percentages were calculated for qualitative variables like gender, viral load, and rapid virological response etc. Over all a $P$ values less than 0.05 was considered statistically significant.

\section{RESULTS}

This study constitutes a total of 95 patients, with chronic hepatitis $\mathrm{C}$ who had initiated treatment with interferon during the one-year study period. Out of the total $35(37 \%)$ of the patients faced early virological failure or viral breakthrough during treatment, discontinued prematurely because of adverse effects, or were lost to followup before reaching the planned EOT. Thus after careful consideration we took 60 patients as study sample who had completed the planned duration of hepatitis C therapy and had undetectable serum HCV RNA. These patients were selected for further analysis. The patients who attained EOT were summarized in Table-I with their main characteristics.

\begin{tabular}{|l|c|}
\hline \multicolumn{2}{|c|}{ Main characteristics } \\
\hline Number of initial patients & 95 \\
\hline EOT completed & 60 \\
\hline Male & $33(55 \%)$ \\
\hline Female & $27(45 \%$ \\
\hline Mean Age +SD & $44+4.5$ \\
\hline Weight & $70.2+15.4$ \\
\hline Genotype \\
\hline 1 & $8(13.3 \%)$ \\
\hline 2 & $9(15.2 \%)$ \\
\hline 3 & $35(58.3 \%)$ \\
\hline 4,5 \& 6 & $8(13.34 \%)$ \\
\hline Sustained virologicresponse (SVR) & $40(70 \%)$ \\
\hline Virologic relapse (VR) & $20(30 \%)$ \\
\hline \multicolumn{2}{|c|}{ Table-I. Main characteristics of the patients } \\
\hline
\end{tabular}

We observed that the patients with relapse were significantly older and heavier ( $P$ value $<0.05$ ). At the start of treatment, viral load was higher in relapsed patients $(P$ value $<0.04)$. Moreover the clinical results were summarized in Table-II.

\begin{tabular}{|c|c|c|c|c|}
\hline Characteristic & All & VR(n=20) & $\operatorname{SVR}(n=40)$ & $P$ value \\
\hline Age & $47.15+9.6$ & $48.2+9.2$ & $46.1+10.1$ & 0.03 \\
\hline Male/Female & $33 / 27$ & $12 / 8$ & $29 / 11$ & NS \\
\hline \multicolumn{5}{|l|}{ Genotype } \\
\hline 1 & $8(13.3 \%)$ & $1(5 \%)$ & $6(15 \%)$ & NS \\
\hline 2 & $9(15.2 \%)$ & $4(20 \%)$ & $9(22.5 \%)$ & \\
\hline 3 & $35(58.3 \%)$ & $13(65 \%)$ & $20(50 \%)$ & \\
\hline 4 & $8(13.34 \%)$ & $2(10 \%)$ & $5(12.5 \%)$ & \\
\hline \multicolumn{5}{|l|}{ Fibro-test stage } \\
\hline $\mathrm{A} 0-\mathrm{A} 1$ & $14(23.34 \%)$ & $5(25 \%)$ & $9(22.5 \%)$ & NS \\
\hline A2-A3 & $46(76.66 \%)$ & $15(75 \%)$ & $31(77.5 \%)$ & \\
\hline F0-F1 & $40(66.67 \%)$ & $12(60 \%)$ & $24(60 \%)$ & \\
\hline F2-F3 & 20 (33.333\%) & $8(40 \%)$ & $16(40 \%)$ & \\
\hline \multicolumn{5}{|l|}{ Viral Load } \\
\hline Total & $6.1+0.68$ & $6.3+0.7$ & $5.9+0.67$ & 0.02 \\
\hline ALAT * Normal & $2.7+1.05$ & $2.0+1.1$ & $3.4+1.01$ & NS \\
\hline \multicolumn{5}{|l|}{ Type of Interferon } \\
\hline $2 a$ & $40(70 \%)$ & $16(80 \%)$ & $25(62.5 \%)$ & \\
\hline $2 b$ & $20(30 \%)$ & $4(20 \%)$ & $15(37.5 \%)$ & 0.001 \\
\hline \multicolumn{5}{|c|}{ Response during Treatment } \\
\hline RVR & & $3(15 \%)$ & $21(52.5 \%)$ & \\
\hline EVR & & $9(45 \%)$ & $14(35 \%)$ & 0.001 \\
\hline No EVR & & $8(40 \%)$ & $5(12.5 \%)$ & 0.002 \\
\hline Hemoglobin at EOT & $11.65+2.1$ & $11.9+2.2$ & $11.4+2.0$ & 0.03 \\
\hline Decline in HCV RNA & $3.7+2.16$ & $3.4+2.3$ & $4.0+2.02$ & 0.004 \\
\hline
\end{tabular}




\section{DISCUSSION}

This is the first study, which determines the relapse of HCV among patients taking interferon therapy in Pakistan. This also determine the significance of association of relapse with various clinical and treatment factors. Some of these factors were identified in various published studies. ${ }^{15}$ In our study we observe that the patient with relapse were significantly older and heavier. This is similar to the findings in other published reports. ${ }^{15,16}$ High body weight has been associated with relapse, In Pakistan; interferon always comes in a dose of $180 \mathrm{mcg}$ while the ribavirin dose was adjustable per the body weight. Some other studies emphasized to avoid the under dosage for both therapies in heavier patients. ${ }^{17} \mathrm{We}$ also report higher hemoglobin level at EOT in relapsed patients. This finding is similar to the results of Sulkowski et al. ${ }^{18}$ By implementing the standard dose of interferon constant and controlling the other factors the patient was experiencing lower relapse rate while ribavirin required weight based dosage to attain better relapse rate. This is in correspondence to the results of Fried at al. ${ }^{19}$ We observe in our study that the standard dosage of interferon (180mcg) in HCV patients with genotype 2 impact significantly to produce relapse rate. This is more in patients failing to achieve a RVR. Previously a study by Francois et al. ${ }^{20}$ confirms the earlier statement. However, absence of RVR works as a predictor for $\mathrm{HCV}$ relapse. Moreover our study highlights the time at which viral eradication after EOT was considered. Our study reported that out of 20 relapse patients 19 were with HCV RNA, which was detected at EOT. We report no significance to the relapse rate at 12 and 24 weeks after the EOT. This is similar to the other published findings. ${ }^{17,20,21}$ Maximum of the relapse had been detected at $8^{\text {th }}$ week after EOT. Some of the other studies show relapse was detected at $12^{\text {th }}$ week after EOT. ${ }^{16}$ However we may conclude the appearance of relapse as early may help us to maximize the success of treatment therapy. It is foresaid that the late relapse is rare, but was nevertheless observed in this study as in previous studies. ${ }^{16}$ In our study the viral load was very less in relapsed patients, which was less than 2 log of the baseline value. The study of Hoefs et al. also observes the same. ${ }^{23}$ An immunomodulatory response against HCV may be due to the interferon induction and may therefore sustainably lower viral load (as observed in the present study). Higher "ALT levels" can sometimes suggest relapse before the reappearance of HCV RNA, but this parameter is not sufficiently reliable.

\section{CONCLUSION}

On the bases of our study findings, we can conclude that low incidence of relapse occur with interferon therapy. High ALT level, viral loads, older age and obesity may be the some of strong predictors of relapse among HCV patients.

Copyright (C) 15 Nov, 2017.

\section{REFERENCES}

1. Shiffman ML. Management options in nonresponders to previous HCV therapy. London: Science Press. 2004:122-125.

2. Sherlock S. Chronic hepatitis C. Dis Mon 1994; 40:117196.

3. Alter MJ, Hadler SC, Judson FN, Mares A, Alexander J, Hu PY, Miller JK, et al. Risk factors for acute non-A, non-B hepatitis in the United States and association with hepatitis C virus infection. JAMA 1990; 264:22312235.

4. Shakil AO, Conry-Cantilena C, Alter HJ, Hayashi P, Kleiner DE, Tedeschi V, Krawczynski K, et al. Volunteer blood donors with antibody to hepatitis $\mathrm{C}$ virus: clinical, biochemical, virologic, and histologic feat.

5. Patel A, Sherlock S, Dusheiko G, Scheuer P, Ellis LA, Ashrafzadeh P. Clinical course and histological correlations in post-transfusion hepatitis $\mathrm{C}$ : the Royal Free Hospital experience. Eur J Gastroenterol Hepatol 1991;3:491-495.

6. Manns M, McHutchison J, Gordon S, et al. Peginterferon alfa-2b plus ribavirin compared with interferon alfa$2 b$ plus ribavirin for initial treatment of chronic hepatitis C: a randomised trial. Lancet 2001; 358 : 958-65.

7. Fried $M$, Shiffman $M$, Reddy $K$, et al. Peginterferon alfa-2a plus ribavirin for chronic hepatitis $C$ virus infection. N Engl J Med 2002; 347:975-82.

8. Jacobson I, Brown R, Freilich B, et al. Peginterferon alfa-2b and weightbased or flat-dose ribavirin in chronic hepatitis C patients: a randomized trial. Hepatology 2007; 46:971-81. 
9. Dore G, Torriani F, Rodriguez-Torres M, et al. Baseline factors prognostic of sustained virological response in patients with HIV-hepatitis $\mathbf{C}$ virus co-infection. AIDS 2007; 21:1555-9.

10. Martin-Carbonero L, Nunez M, Marino A, et al. Undetectable hepatitis C virus RNA at week 4 as predictor of sustained virological response in HIV patients with chronic hepatitis C. AIDS 2008; 22:1521.

11. Marcellin P, Boyer N, Gervais A, et al. Long-term histologic improvement and loss of detectable intrahepatic HCV-RNA in patients with chronic hepatitis $\mathbf{C}$ and sustained response to interferon alpha therapy. Ann Intern Med 1997; 127:875-81.

12. Veldt B, Saracco G, Boyer N, et al. Long term clinical outcome of chronic hepatitis $\mathrm{C}$ patients with sustained virological response to interferon monotherapy. Gut 2004; 53:1504-8.

13. Jones R, Brown D, Nelson M, et al. Hepatitis C viremia following sus tained virological response to pegylated interferon and ribavirin in HIV+ men who have sex with men: reinfection or late relapse [abstract LB61]? In: Program and abstracts of the 15th Conference on Retroviruses and Opportunistic Infections (Boston). University of California, San Diego, 2008.

14. Zeuzem S, Heathcote E, Shiffman M, et al. Twelve weeks of follow-up is sufficient for the determination of sustained virologic response in patients treated with interferon alpha for chronic hepatitis C. J Hepatol 2003; 39:106-11.

15. Kurosaki M, Hiramatsu N, Sakamoto M, Suzuki Y, Iwasaki M, Tamori A, Matsuura K, Kakinuma S, Sugauchi F, Sakamoto N, Nakagawa M, Yatsuhashi H, Izumi N. 2012. Age and total ribavirin dose are independent predictors of relapse after interferon therapy in chronic hepatitis $\mathrm{C}$ revealed by data mining analysis. Antivir Ther 17:35-43.

16. Martinot-Peignoux M, Stern C, Maylin S, Ripault MP, Boyer N, Leclere L, Castelnau C, Giuily N, El Ray A, Cardoso AC, Moucari R, Asselah T, Marcellin P. 2010. Twelve weeks post- treatment follow-up is as relevant as 24 weeks to determine the sustained virologic response in patients with hepatitis $\mathbf{C}$ virus receiving pegylated interferon and ribavirin. Hepatology 51 : 1122-1126.
17. Namikawa M, Kakizaki S, Yata Y, Yamazaki Y, Horiguchi N, Sato K, Takagi H, Mori M. 2012. Optimal follow-up time to determine the sustained virological response in patients with chronic hepatitis $\mathrm{C}$ receiving pegylated-interferon and ribavirin. J Gastroenterol Hepatol 27:69-75.

18. Sulkowski MS, Shiffman ML, Afdhal NH, Reddy KR, McCone J, Lee WM, Herrine SK, Harrison SA, Poordad FF, Koury K, Deng W, Noviello S, Pedicone LD, Brass CA, Albrecht JK, McHutch- ison JG. 2010. Hepatitis C virus treatment-related anemia is associated with higher sustained virologic response rate. Gastroenterology 139:1602-1611; e1601.

19. Fried MW, Jensen DM, Rodriguez-Torres $M$, Nyberg LM, Di Bisceglie AM, Morgan TR, Pockros PJ, Lin A, Cupelli L, Duff F, Wang K, Nelson DR. 2008. Improved outcomes in patients with hepatitis $\mathbf{C}$ with difficultto-treat characteristics: Randomized study of higher doses of peginterferon alpha-2a and ribavirin. Hepatology 48:1033-1043.

20. Francois C, Coulouarn C, Descamps V, Castelain S, Brochot E, Baron A, Duchaussoy I, Capron D, NguyenKhac E, Duverlie G. 2012. The treatment response of chronically hepatitis $\mathrm{C}$ virus- infected patients depends on interferon concentration but not on interferon gene expression in peripheral blood mononuclear cells. Antimicrob Agents Chemother 56:903-908.

21. Zuzem S, Heathcote EJ, Shiffman ML, Wright TL, Bain VG, Sherman M, Feinman SV, Fried MW, Rasenack J, Sarrazin C, Jensen DM, Lin A, Hoffman JH, Sedarati F. 2003. Twelve weeks of follow-up is sufficient for the determination of sustained virologic response in patients treated with interferon alpha for chronic hepatitis C. J Hepatol 39:106-111.

22. Medrano J, Barreiro P, Resino S, Tuma P, Rodriguez V, Vispo E, Labarga P, Madejon A, Garcia-Samaniego J, Jimenez-Nacher I, Martin-Carbonero L, Soriano V. 2009. Rate and timing of hepatitis $\mathbf{C}$ virus relapse after a successful course of pegylated interferon plus ribavirin in HIV-infected and HIV-uninfected patients. Clin Infect Dis 49:1397-1401.

23. Hoefs JC, Aulakh VS, llagan BJ. 2012. Very low viral load (VLVL) relapse following treatment of naive patients with chronic hepatitis C. Dig Dis Sci 57:243249. 


\section{PREVIOUS RELATED STUDY}

Dilshad Muhammad, Khalid Amin, Amin Anjum, Masood Javed. Chronic hepatitis C virus, Infection; association with type 2 diabetes mellitus (Original) Prof Med Jour 17(4) 557-562 Oct, Nov, Dec 2010.

Fatima Mehboob, Zafar Majeed Babar. Hepatitis c patients; treatment compliance of having poor socio-economic back ground (Original) Prof Med Jour 15(1) 61-66 Jan, Feb, Mar, 2008.

Faqir Muhammad Tariq, Habib Subhani, Irshad Ahmad, Irshad ul Haq. Hepatitis C; prevalence in paramedical staff of a teaching hospital (Original) Prof Med Jour 16(2) 168-172 Apr, May, Jun, 2009.

Muhammad Afzal, Irfan Ahmed Mughal, Naushen Afzal, Muhammad Badar Bashir, Fiyaz Ahmed Malik. CHRONIC Hepatitis $\mathrm{C}$ infection; correlation of glucose tolerance test, the levels of fasting blood sugar (FBS) and hemoglobin (Original) Prof Med Jour 11(2) 222-227 Apr, May, Jun, 2004.

S. M. Abbas Naqvi, Qurban ali Khaskheli, Shahid Habib Ansari, Muhammad Shiraz Khan, Muhammad Saeed Talpur. Hepatitis C virus; Prevalence in blood donors in Karachi (Original) Prof Med Jour 13(4) 604-607 Oct, Nov, Dec, 2006.

Shaukat Ali, Syed Khurram Shahzad, Atiq ur Rehman Slehria. Chronic hepatitis C; response to interferon and ribavirin combination (Original) Prof Med Jour 17(4) 563-567 Oct, Nov, Dec 2010.

Waheed Ahmed, Manzar Zakaria, Syed Badshah Hussain Zaidi. Hepatitis C; frequency of thrombocytopenia patients treated with interferon (Original) Prof Med Jour 17(1) 117-121 Jan, Feb, Mar 2010.

\section{6}

\section{Being honest may not get you a lot of FRIENDS but it'll always get you RIGHT ONES.}

AUTHORSHIP AND CONTRIBUTION DECLARATION

\begin{tabular}{|c|c|c|c|}
\hline Sr. \# & Author-s Full Name & Contribution to the paper & Author $=s$ Signature \\
\hline 1 & M. Khuram Nouman & First Author & \\
\hline 2 & Bushra Zaidi & Second Author & \\
\hline 3 & Ghulam Mohiuddin & Third Author & \\
\hline 4 & Faryal Asif & Others & \\
\hline 5 & M. Khan Malik & Others & \\
\hline
\end{tabular}

